\title{
Toponyms in IvE 672 and IvE 3080: interpreting collective action in honorific inscriptions from Ephesos ${ }^{1}$
}

Titus Flavius Damianus is one of the best known citizens of Ephesos ${ }^{2}$. A record of his life is preserved in a short biography by Philostratus ${ }^{3}$, in twelve inscriptions from Ephesos ${ }^{4}$, and in the archaeological record of the city. These complementary sources present, in fragments, aspects of the life of an individual who was a professional teacher of rhetoric, an office-holding civic notable, and a major benefactor in Ephesos during the second half of the $2^{\text {nd }}$ century $\mathrm{AD}$. The picture of Damianus and his life that these sources permit us to develop may well be one of the fuller that we have for non-imperial personages in the provinces. We know about his marriage to Vedia Phaedrina ${ }^{5}$, the daughter of another famous Ephesian, P. Vedius Antoninus ${ }^{6}$; we know about the couple's numerous children (and from other inscriptions, about their children's careers as senators, and about the careers of their grandchildren); we know about Damianus' ties to representatives of the Roman imperial government stationed in the province of Asia; and we know about his generous benefactions to the city of Ephesos, not only via the epigraphic and literary sources, but because the porticoes which he and his wife, Vedia Phaedrina, built from the city to the Artemision have been the subject of intensive investigation by the Austrian Archaeological Institute since the 1990s ${ }^{7}$.

In this paper, I concentrate on the two most informative inscriptions concerning Damianus, IvE 672 and IvE 3080. They are both inscribed bases which supported statues erected to honour him for a series of benefactions that he undertook when he was grammateus or secretary of the demos ${ }^{8}$. They have been securely dated to 166/67 because they refer to the fact that Damianus received and entertained at Ephesos for several months the army returning victorious from Lucius Verus' Parthian campaign ${ }^{9}$. Both were found by early $20^{\text {th }}$ century excavators, reused in the building of later walls. IvE 672 was found reused near the Octagon, located in front of Terrace House 2 (fig. 1 no. 51), while IvE 3080 was one of numerous bases extracted by

\footnotetext{
${ }^{1}$ A version this paper was presented in the 'Hauskolloquium' of the Institute of Classical Archaeology at the University of Vienna in November 2005. I thank the audience for their comments and questions. I especially thank Hans Taeuber for comments on the text of this paper and for additional bibliography. - Abbrevations follow the guidelines published in ÖJh 69, 2000, $357 \mathrm{ff}$. (http:// www.oeai.at/publik/autoren.html), additionally used is: IvE = Inschriften griechischer Städte aus Kleinasien 11, 1 (1979) - 17, 4 (1984), Ephesos (IvE Ia - VIII 2).

2 PIR $^{2}$ F 253.

${ }^{3}$ Philostr. soph. 2, 23.

${ }^{4}$ IvE 672. 672A. 672B. 676A. 678. 735. 811. 2100. 3029. 3051. 3080. 3081.

${ }^{5}$ M.-Th. Raepsaet-Charlier, Prosopographie des femmes de l'ordre sénatorial, I-II' siècles (1987) no. 784.

${ }^{6}$ J. Keil in: RE VIIIA (1955) 566 f. s. v. Vedius 3.

7 The so-called Stoa of Damianos was mentioned in Philostratus' biography of Damianus as a weather-proof link of the city to the Artemision. In the 1860s, John Turtle Wood used the narrative of Philostratus to locate the stoa, which eventually lead him to the temenos wall and to the temple of Artemis itself, see J. T. Wood, Discoveries at Ephesus (1877). In the 1990s, a team from the Austrian Archaeological Institute directed by Dieter Knibbe began a multi-year investigation of the stoa, establishing a clearer picture not only of its course and architectural form, but also of its role as a site of cult and burial, see D. Knibbe - G. Langmann (eds.), Via Sacra Ephesiaca I, BerMatÖAI 3 (1993) and D. Knibbe - H. Thür (eds.), Via Sacra Ephesiaca II, BerMatÖAI 6 (1995). These investigations have been continued in recent years in rescue excavations directed by Martin Steskal, which continue to shed light on the stoa and its burials, see M. Steskal et al., Die Damianosstoa in Ephesos. Bericht über die Ausgrabung 2002 im Abschnitt Kathodos III, ÖJh, 72, 2003, 241-273. On environmental reasons for the construction of the Damianos Stoa, see W. Vetters - H. Zabehlicky, Eine Klimatkatastrophe um 200 n. Chr. und ihre archäologisch-historische Nachweisbarkeit, in: Archäologie - Naturwissenschaften - Umwelt (2001) 9-12.

${ }^{8}$ IvE 672 and 3080 state only that he was grammateus or secretary, however IvE 811, 1l. 24-27, erected in the same year, clarifies that he was specifically grammateus of the demos.

${ }^{9}$ G. Alföldy - H. Engelmann, Iunius Maximus und die Victoria Parthica, ZPE 35, 1979, 195-213.
} 


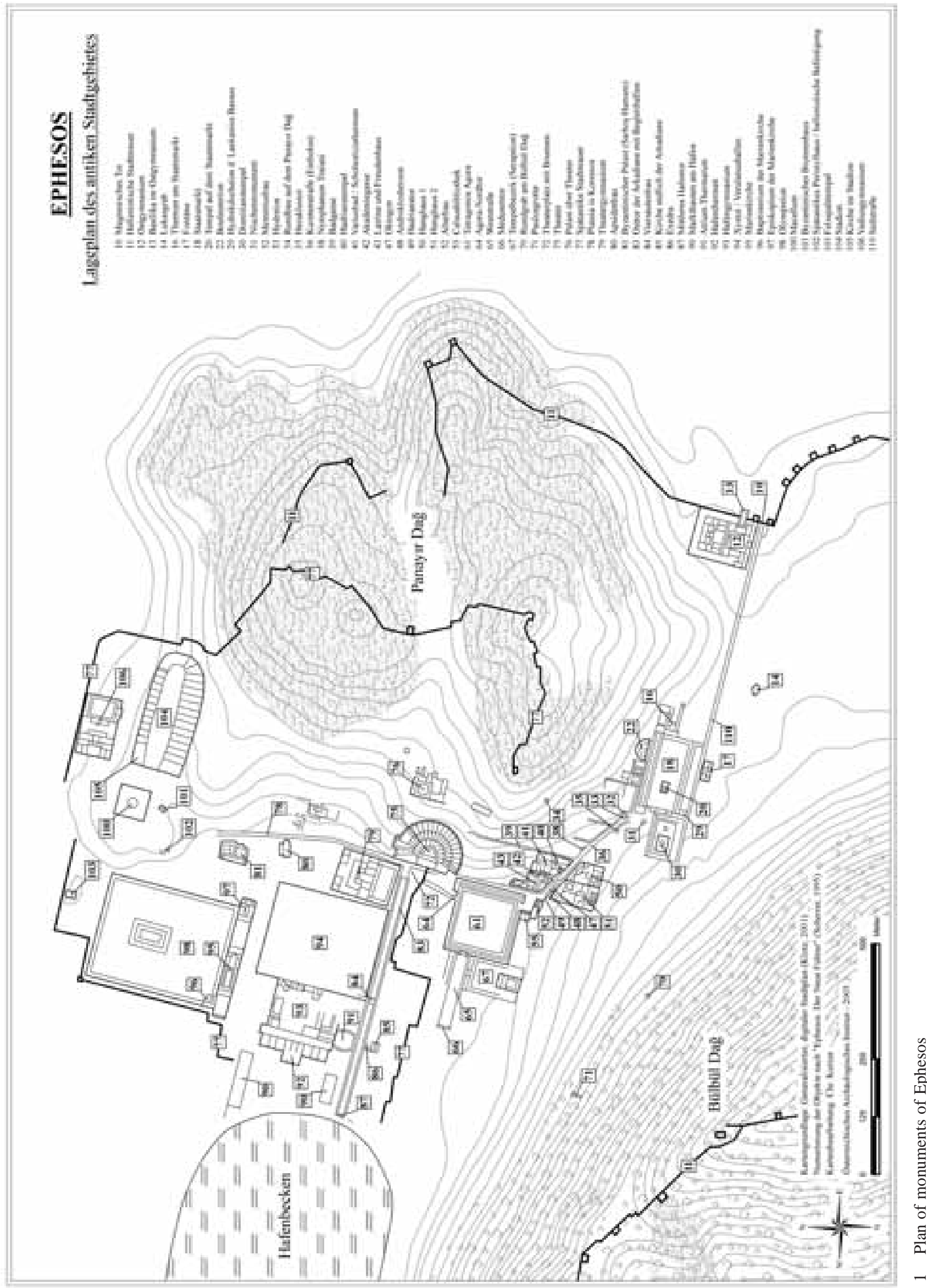


W. Wilberg and J. Keil from a late antique wall in the northeast corner of the Tetragonos Agora (fig. 1 no. 61) ${ }^{10}$.

They are also examples of parallel texts. That is, they contain precisely the same information concerning the benefactions of Damianus, expressed in almost precisely the same language, but they were erected by two different groups, who identify themselves by place name. It is this collective activity undertaken by groups identified by toponyms that I wish to explore here.

In the corpora of inscriptions of Asia Minor and elsewhere honorific texts erected by collectives, for example workers' or professional associations, are common $^{11}$. But the erection of honorific monuments by collectives identified by toponyms opens up a host of questions that have been relatively unexplored, and which I hope to address here. Some of these questions are very specific to the site of Ephesos, while others have broader implications for other ancient cities where similar inscriptions are found. What motivated these particular areas in Ephesos to honour Damianus? To answer this question adequately we must consider questions of topography: where a particular area was located and what its social and economic character was. Other questions have broader implications for the social and political organization of the city. How were collectives, which were identified by areas of a city organized that they were able to erect an honorific monument to a benefactor? And what was the relationship of such collectives to other civic bodies, such as boule and demos? Furthermore, in the case of

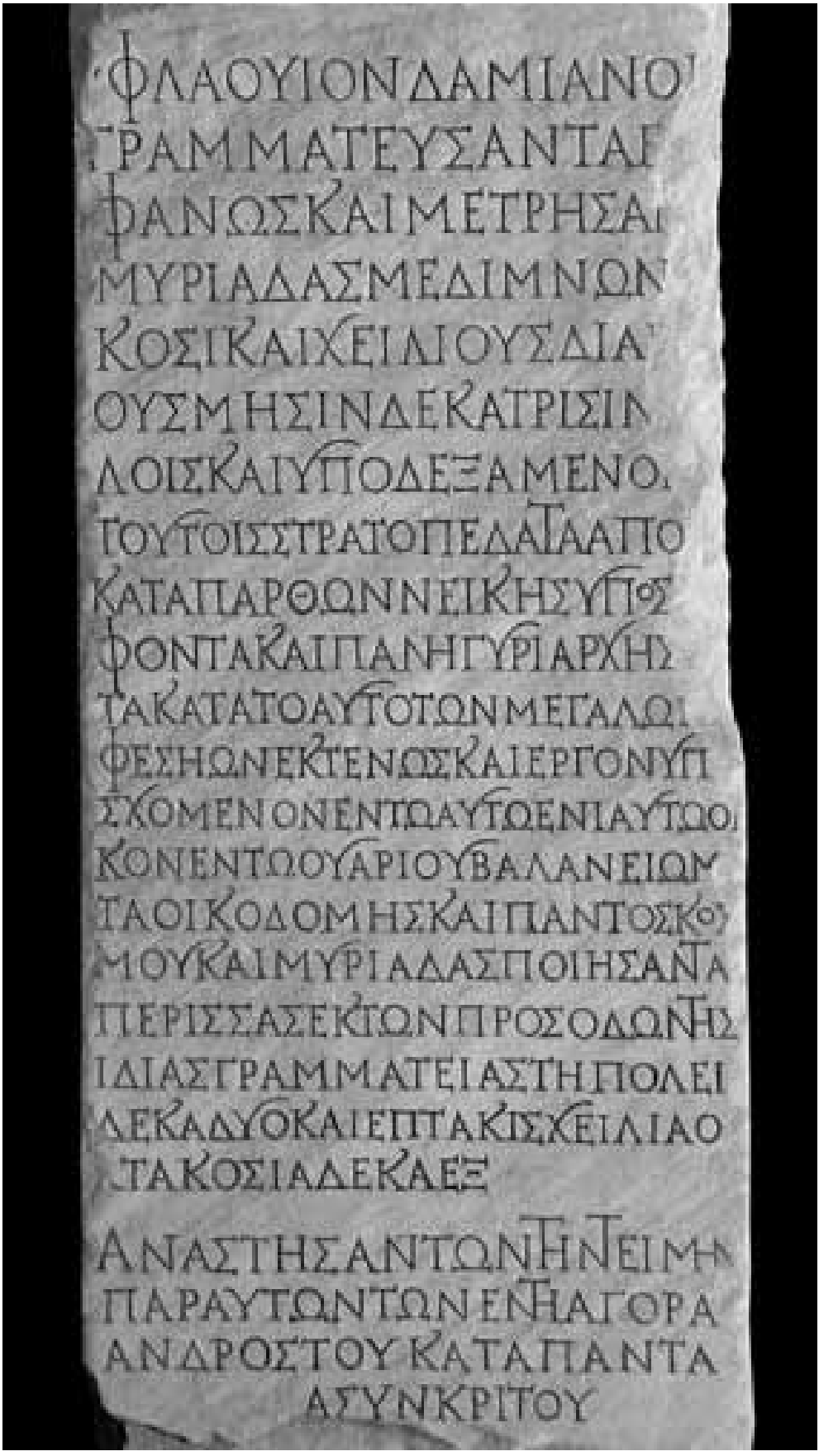

2 IvE 672 the two parallel texts from Ephesos, how do these two areas come to erect virtually the same text to Damianus? In short, instead of concentrating on the benefactor, Damianus, we will look closely at the identity and motivations of the collectives who honoured him.

\footnotetext{
${ }^{10}$ On the description of where IvE 672 was found see R. Heberdey, IX. Vorläufiger Bericht über die Grabungen in Ephesos 19071911, ÖJh 15, 1912, 164-165. On the discovery of IvE 3080, see W. Wilberg in: FiE III (1923) 2.

${ }^{11}$ O. van Nijf, The civic world of professional associations in the Roman East (1997) 73-130.
} 


\section{The content of the inscriptions}

IvE 672 (fig. 2)

\begin{tabular}{|c|}
\hline 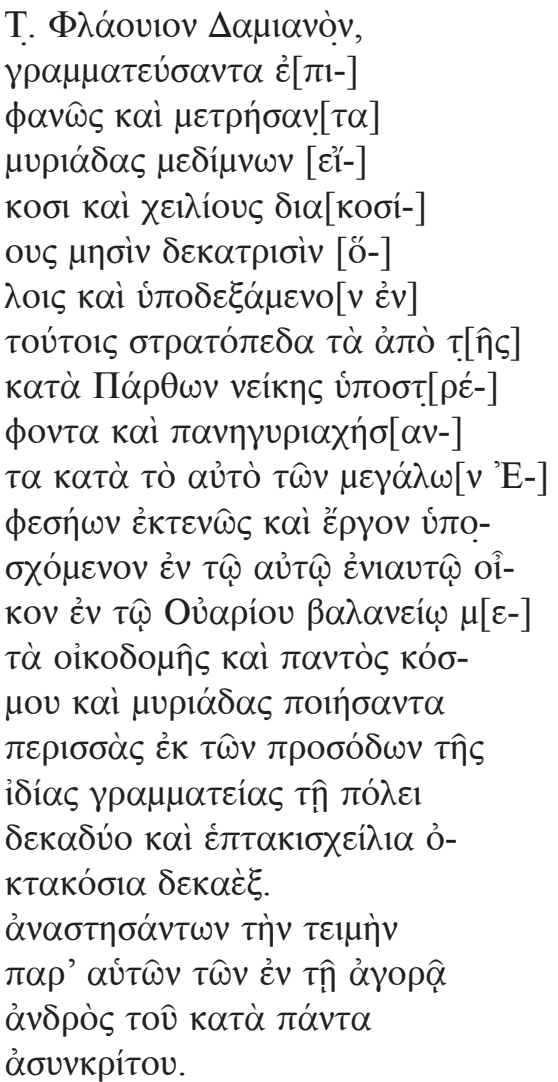 \\
\hline
\end{tabular}

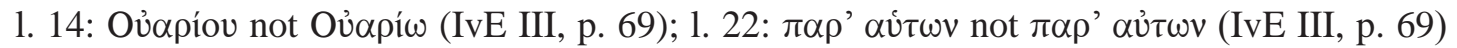

»[... The boule and the demos honour] T. Flavius Damianus who performed the office of secretary conspicuously, and measured out 201,200 measures (of grain) for thirteen whole months, and received at this time the army returning from the victory against the Parthians, and zealously at the same time was president of the great Ephesia, and promised a structure in the same year, a hall in the baths of Varius with the architecture and all of the decoration, and he made for the city a surplus of 127,816 (denarii) from the revenues of his own term as secretary. From their own funds, those in the agora (who are supporters) of a man incomparable in all respects set up this honour.«

IvE 3080 (fig. 3)

T. $\Phi \lambda . \Delta \alpha \mu 1 \alpha v o ̀ v$

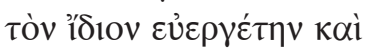

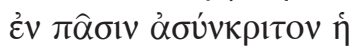
$\pi \lambda \alpha \tau \varepsilon \hat{\imath} \alpha, \gamma \rho \alpha \mu \mu \alpha \tau \varepsilon v ́ \sigma \alpha v \tau \alpha$

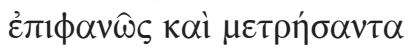
$\mu v p i \alpha ́ \alpha \alpha \varsigma \mu \varepsilon \delta i ́ \mu v \omega v \kappa^{\prime} \kappa \alpha i$,

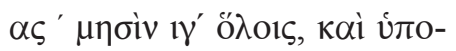
$\left.\delta \varepsilon \xi \dot{\alpha}_{\mu \varepsilon v o v} \varepsilon\right\urcorner v \tau o u ́ \tau O 1 \varsigma \sigma \tau \rho \alpha-$ 


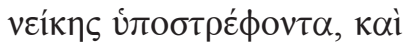

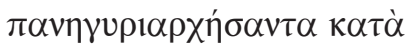

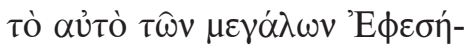

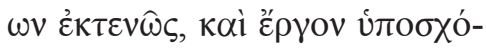

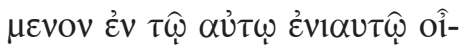

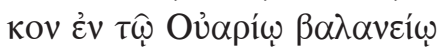

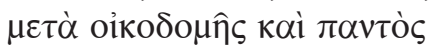

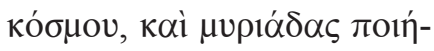

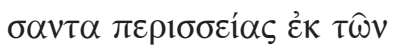

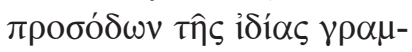

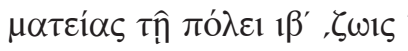

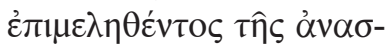

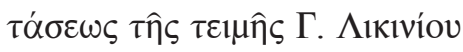

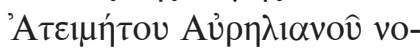

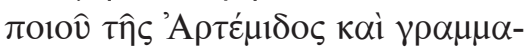

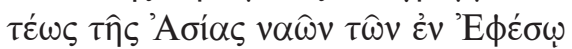

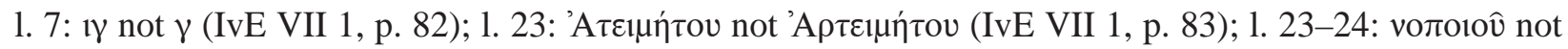
ขยо

»T. Flavius Damianus, their own benefactor and a man incomparable in all respects, the plateia (honours); he performed the office of secretary conspicuously, and measured out 201,200 measures (of grain) for thirteen whole months, and received at this time the army returning from the victory against the Parthians, and zealously at the same time was president of the great Ephesia, and promised a structure in the same year, a hall in the baths of Varius, with the architecture and all of the decoration, and he made for the city a surplus of 127,816 (denarii) from the revenues of his own term as grammateus. G. Licinius Ateimetos Aurelianus, neopoios of Artemis and secretary of Asia of the temples in Ephesos took charge of setting up of this honour."

The parallel inscriptions honour Damianus for exactly the same reasons, presented in the same order. While Damianus was grammateus or secretary of the demos he performed numerous outstanding benefactions, which went well beyond the duties of his magistracy ${ }^{12}$. He

${ }^{12}$ C. Schulte, Die Grammateis von Ephesos (1994) 40-45. By the $2^{\text {nd }}$ century, the grammateus of the demos was the most important of Ephesos' several grammateis, introducing motions to the ecclesia, and undertaking a variety of financial duties.

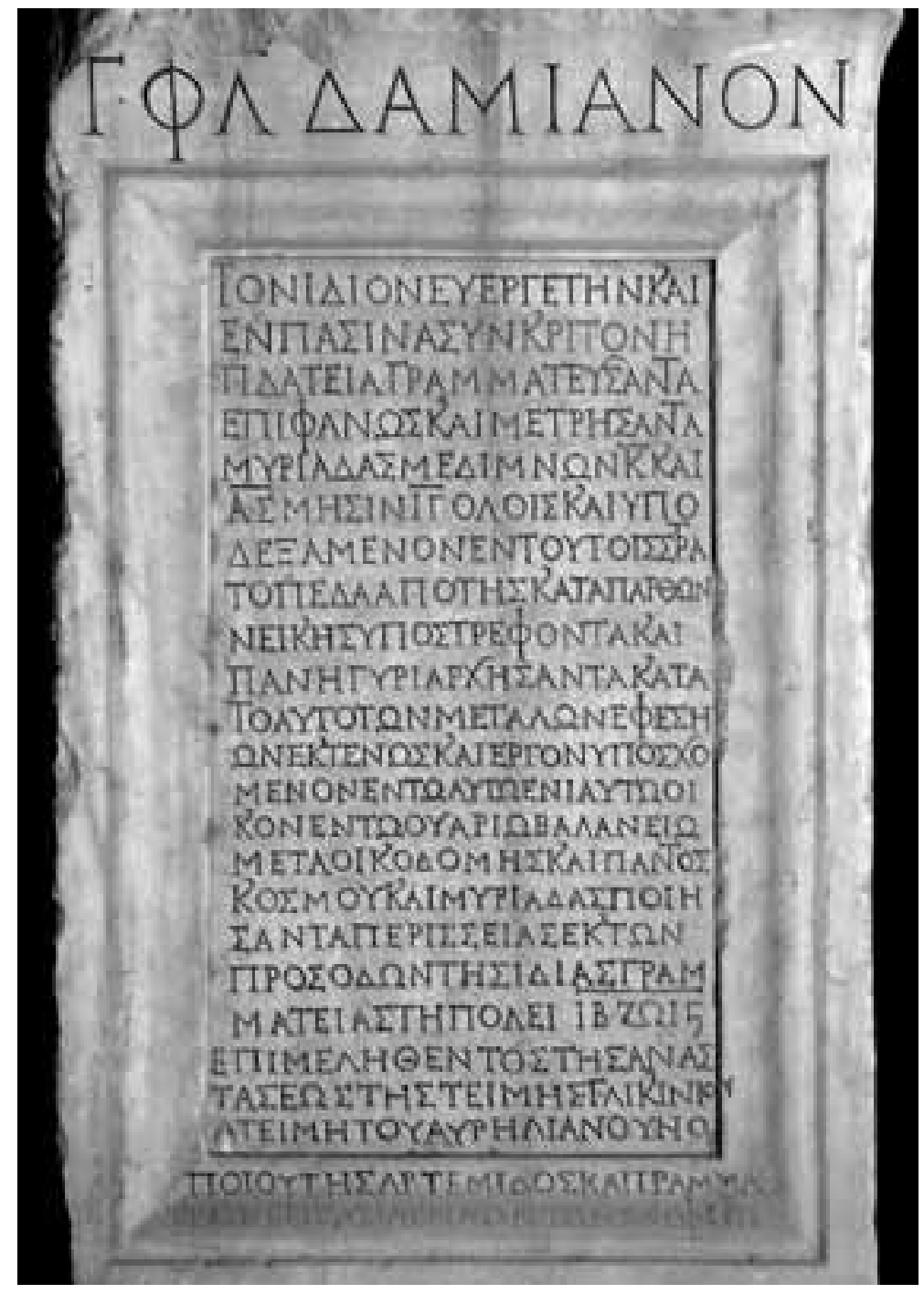

$3 \quad$ IvE 3080 
supplied 201,200 medimnoi of grain over a period of thirteen months, presumably paying for $\mathrm{it}^{13}$. At the same

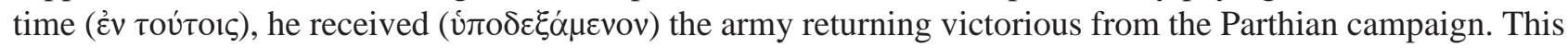
must mean that he billeted them on his own vast estates, or that he paid for their billeting among the civilian population. Most of the scholarship has connected these two events, arguing that Damianus supplied grain to the soldiers billeted in the city ${ }^{14}$. Both inscriptions indicate that in the same year, Damianus also performed

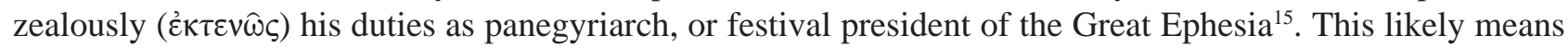
that he contributed financially to the production of the festival, since it is clear from the edict of the proconsul Paullus Fabius Persicus dated to $44 \mathrm{AD}$ that the expenditures from civic or temple funds for the festival were limited to 4,500 denarii, which is not very much money for a splendid festival ${ }^{16}$. In addition, Damianus promised to build and decorate a hall (oîkoఢ) in the Baths of Varius. These baths had been built in the Hadrianic period by P. Quintilius Valens Varius ${ }^{17}$. Damianus' project is described as the construction and decora-

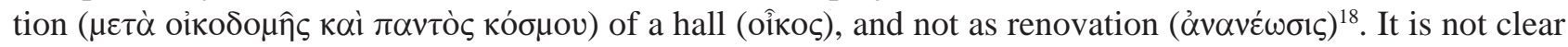
what Damianus built here because of the $4^{\text {th }}$ century renovation by Scholastikia ${ }^{19}$, however, the largest room in the structure, the apsidal hall, may be the best candidate (fig. 1, 41 and fig. 4, V) ${ }^{20}$. Finally, Damianus is honoured for making the city 127,816 denarii excess revenue from his term as secretary of the demos. It appears that his management of civic revenues was so efficient and honest that at the end of his term of office he chose to return profits to the city, instead of spending them on frivolities (or pocketing them himself) ${ }^{21}$. This was evidently remarkable and rare enough to be mentioned in this honorific text.

Although they differ substantially in appearance (figs. 2 and 3), in terms of content and language, the differences between the parallel texts are few ${ }^{22}$. In IvE 672, it is in the final four lines of the inscription that we

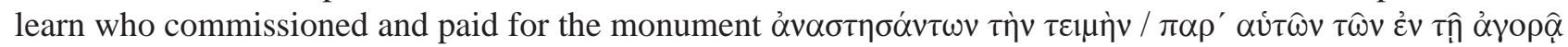

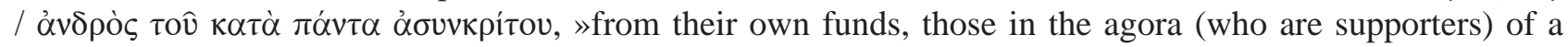
man incomparable in all respects set up this honour«. By contrast, this information is given in lines 2-3 of IvE 3080, where we learn that $\dot{\eta} \pi \lambda \alpha \tau \varepsilon \hat{\imath} \alpha$, (the people of) »the plateia « erected the monument for $\tau$ òv ' i $\delta 10 v$

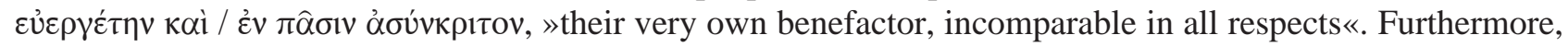
lines 22-26 indicate that G. Licinius Ateimetos Aurelianus, neopoios of Artemis and secretary of the temples of Asia in Ephesos was charged with the task of seeing to the erection of the monument.

\footnotetext{
131 medimnos $=$ 51,84 litres or 11,40 gallons; 201,200 medimnoi = 10,430,208 litres or 2,293,680 gallons of grain.

${ }^{14}$ Alföldy - Engelmann (note 9) 209-210; B. Peuch, Orateurs et sophistes grecs dans les inscriptions d’époque impériale (2002) 193 and note 2.

15 The Ephesia is a festival of Artemis with accompanying games. It has been argued that it was not the same as the Artemisia, but was a regional, rather than local, penteteric festival. This is confirmed by a decree of the Dionysian technitai for T. Aelius Alcibiades (IvE 22. 42), which calls the great Ephesia a penteteric agon. Several inscriptions honouring victors refer to $\tau \dot{\alpha} \mu \varepsilon \gamma \alpha \dot{\alpha} \alpha$

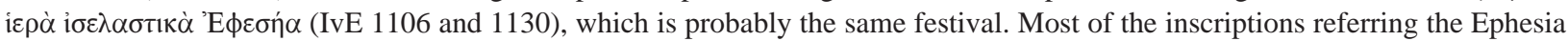
are honorific: for panegyriarchs, see IvE 672. 728. 811. 3080. 1080B. 3014 and 3080; for victorious athletes, see IvE 1123. 1132;

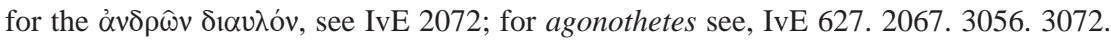

${ }^{16}$ IvE 17-19; IvE 18d, 3-4.

${ }^{17}$ IvE 500. 455.

${ }_{18}$ Although the inscription does not employ the Greek word for renovation, it is worth noting that Philostr. soph. 2, 23 writes that

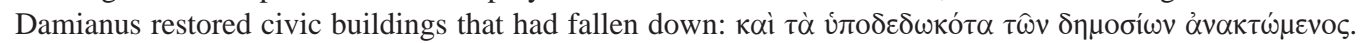

${ }^{19}$ IvE 453, a statue base incription, records Scholastikia’s renovation of the baths. See also F. Miltner, XXI. Vorläufiger Bericht über die Ausgrabungen in Ephesos, ÖJh 43, 1956-58, Beibl. 22-25.

${ }^{20}$ D. Knibbe, Topographica Ephesiaca, ÖJh 71, 2002, 211, and P. Scherrer, The City of Ephesos from the Roman period to Late Antiquity, in: H. Koester (ed.), Ephesos. Metropolis of Asia (1995) 15; both suggest that the oîkoc referred to is a room for imperial cult installed in the Baths by Damianus, although it is not clear upon what evidence they base this assumption.

${ }^{21}$ Schulte (note 12) 40-42 on the financial responsibilities of the grammateus of the demos.

${ }^{22}$ However, there are notable differences in orthography, hand, and physical characteristics of IvE 672 and 3080 . A study of these see my article, Of stones and masons: reflections on the genesis of two parallel texts from Ephesos (IvE 672 and 3080) forthcoming in Tyche 21, 2006.
} 


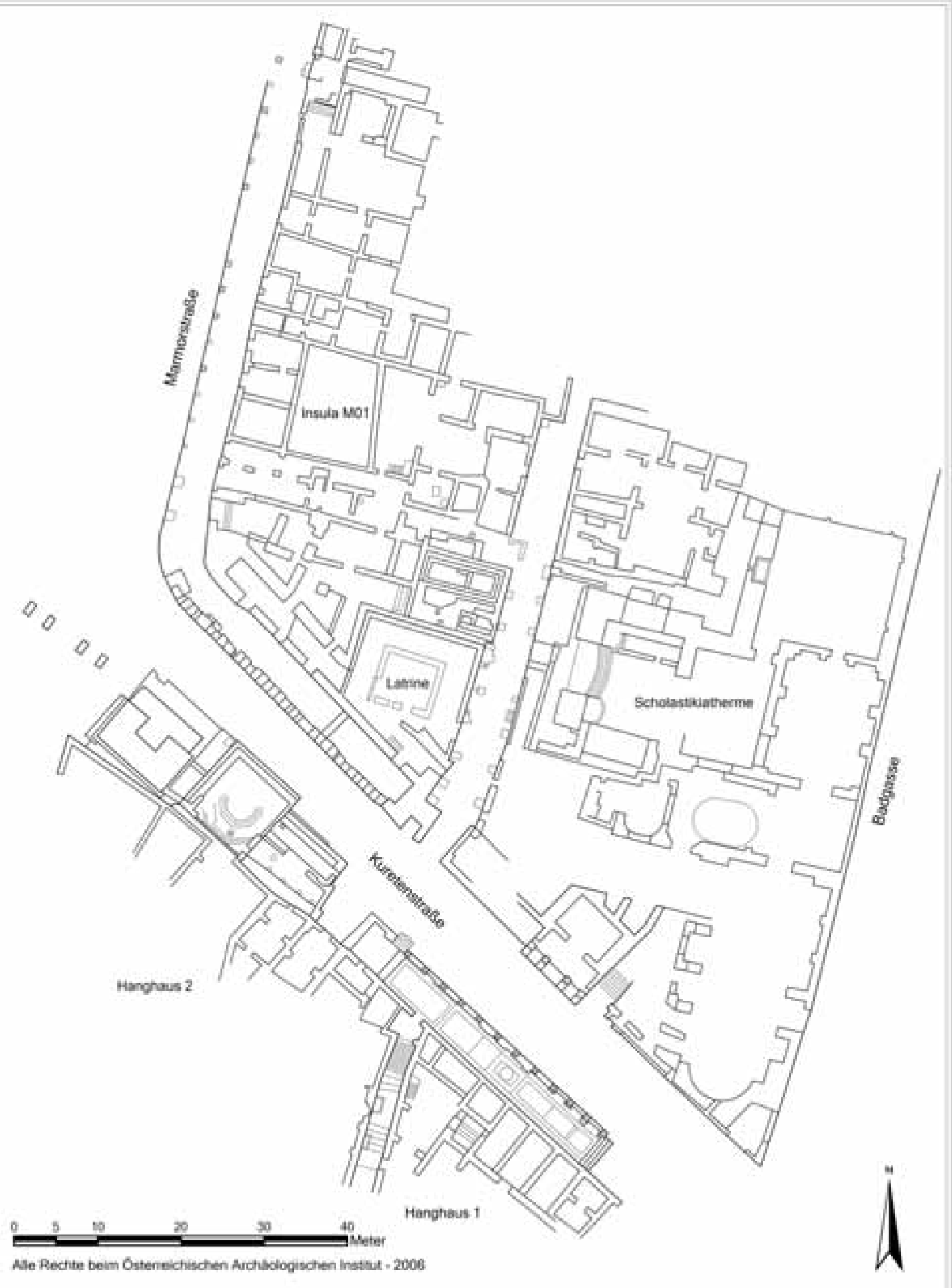

4 Plan of Varius/Scholastikia Baths 


\section{People and places honouring benefactors}

In order to fully understand who are »those of the agora « in IvE 672, and »the plateia« in IvE 3080, we must set them in the context of other Ephesian inscriptions in which collectives identify themselves by toponyms. In a number of these, the groups identify themselves dually, that is, with both workers' or professional as-

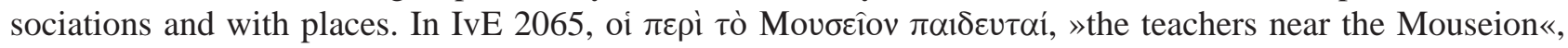

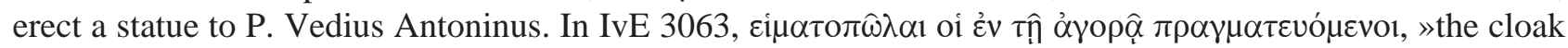
sellers doing business in the agora«, honour M. Fulvius Publicianus Nikephorus for his goodwill towards the

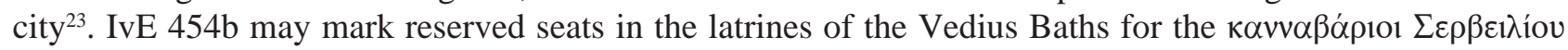
$\sigma \tau o \hat{\alpha} \varsigma$, »the hemp-workers of the stoa of Servilius « ${ }^{24}$. Each of these inscriptions names an association and a place, in each case indicated by naming a particular structure where the association worked or had the seat of its organization.

There are also a few inscriptions where the identification of place is less clear to us, but would have been

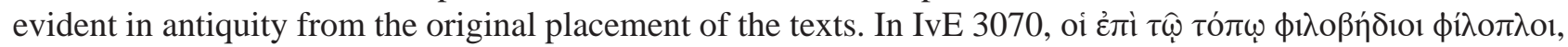
»the arms-loving philovedioi in this place«, honour a civic benefactor whose name is lost. In IvE 3079, oi عُv

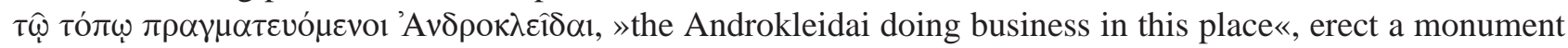
to P. Vedius Papianus Antoninus. It is possible that the place to which of these inscriptions refer is the Tetragonos Agora, since both were found reused in the building of late walls there ${ }^{25}$. In all of the examples listed above, the primary identification of the group is profession, while the secondary one is location or place. This naming of place in collocation with association appears to imply that there were several associations of cloaksellers, for example, and that they distinguished themselves from other cloaksellers by adding a topographical descriptor to their association name.

The parallel texts IvE 672 and IvE 3080 are quite different from these, at least at first glance. In these inscriptions, the groups identify themselves solely by toponym without further descriptors of any kind. This kind of self-identification would appear to cut across boundaries of profession, class, etc., the implication being that all of »the people of the agora«, whoever they might be, and all of »the people of the plateia«, whoever they might be, had come together to honour Damianus the civic benefactor. But who are the "people of agora« and the "people of the plateia«? It is to this question that we now turn.

The agora referred to in IvE 672 must surely be the commercial or Tetragonos Agora, which had rows of shops in its stoai throughout the Hellenistic, Roman and late Roman periods (fig. 1, 61) ${ }^{26}$. In fact, several inscriptions which name workers' associations were found built into late walls here (IvE 3063. 3070. 3079, all discussed above). The "people of the agora « then, seem likely to be those who had their shops and workplaces located in the stoai enclosing its broad open area. The other agora-like space known in Ephesos, the so-called State Agora, is not a candidate since, in the $2^{\text {nd }}$ century, it was lined with buildings of political and religious function rather than with structures of commercial or residential function. It seems likely that »the people of the agora " of IvE 672 was a gathering together of the people belonging to the various kinds of professional and workers' associations located in the Tetragonos Agora.

It is less clear where the $\pi \lambda \alpha \tau \varepsilon \hat{i} \alpha$ mentioned in IvE 3080 is because the evidence for plateiai in Ephesos is more complex. The term plateia occurs in numerous inscriptions from cities in Asia Minor and the Roman east, and generally means a broad, paved, colonnaded street ${ }^{27}$. It occurs in several inscriptions from Ephesos. IvE 3071 (ll. 20-22) describes the paving of a road during the prytany of certain individual: हैv $\tau \varepsilon \tau \hat{\varphi} \kappa \alpha i \rho \hat{\omega} /$

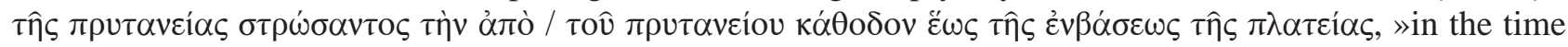
of his prytany he paved the descending road from the prytaneion to the entrance of the plateia«. The editors

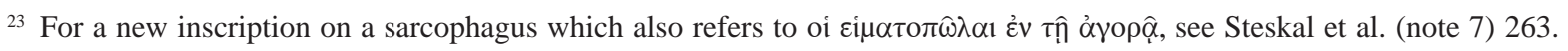

${ }^{24}$ Liddell - Scott, revised supplement (1996) 166.

${ }^{25}$ IvE 3070 was built into the late wall in the northeastern corner of the agora, see Wilberg (note 10) 2. IvE 3079 still forms part of the wall between rooms 2 and 3 of the east colonnade (counting from south to north).

${ }^{26}$ The agora is referred to by this name in the $1^{\text {st }}$ c. AD in IvE 3005 and 4123 (ll. 10). For the history of the structure from the Hellenistic period through the Roman period see P. Scherrer, The historical topography of Ephesos, in: D. Parrish (ed.), Urbanism in Western Asia Minor, 45. Suppl. JRA (2001) 66-67. 73-77. 79-80 and figs. 3-7 and 3-14.

27 L. Robert, Etudes anatoliennes (1979) 532-538. 
of this inscription suggested that the plateia referred to here is the so-called Kuretenstraße (fig. 1,36$)^{28}$. IvE 422A, a very fragmentary architrave inscription found in front of the gate-like structure at the south end of

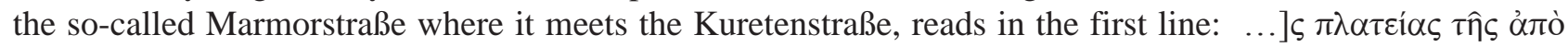

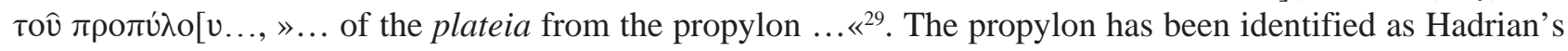
Gate and so the road described may be the Marmorstraße.

In several inscriptions from Ephesos, however, the term plateia is accompanied by a descriptive adjective. IvE 454d, a very short text inscribed on a column found in the latrine of the Vedius Gymnasium, appears to reserve seats for the people of the $\pi \lambda \alpha \tau \varepsilon \hat{i} \alpha$ B $\rho \alpha \chi 1 \alpha v \hat{\eta}$. IvE 626, an inscription reused in the stadium, mentions

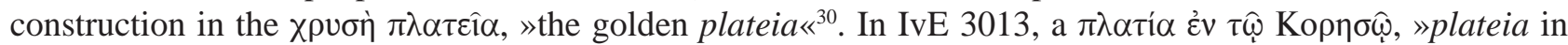
Koressos « was paved by an agoranomos in the $3^{\text {rd }}$ century ${ }^{31}$. Reviewing this evidence, both Hilke Thür and Peter Scherrer have argued that there was a single plateia in Ephesos, and that it was the archaic processional route which ran through the whole city: »Theoretisch könnte es in Ephesos mehrere Straßen mit Bezeichnung Plateia gegeben haben. Faßt man jedoch die Aussagekraft der oben genannten Texte zusammen, so entsteht der Eindruck, daß Plateia eine ganz bestimmte breite und große Straße meint: 1 . In sie mündet eine Straße ein, die vom Prytaneion kommt, 2. sie liegt in der Nähe des Hadrianstores, 3. sie verläuft nicht allzuweit entfernt vom Vediusgymnasium (sonst wären dort reservierte Latrinenplätze sinnlos) und 4. berührt sie auch den Stadtteil Koressos. Alle diese Forderungen erfüllt alleine die Trasse des alten Prozessionsweges, der im Verlaufe der Kuretenstraße zwischen den beiden Stadtbergen zum Hadrianstor hinabführt, von dort die Marmorstraße entlang bis zum Theater verläuft und weiter nach Norden zwischen Stadion bzw. Vediusgymnasium und dem westlich davon liegenden Hügel zum Koressischen Tor führt. Einzelne Abschnitte der durchgängig Plateia genannten Straße dürften spezielle Bezeichnungen getragen haben, etwa >Branchiane «. ${ }^{32}$

This proposition is attractive because it sensibly incorporates the topographical references made in IvE 3071, 422A, 454d and 3013, and at the same time allows for individual sections of the processional road to be named with specific descriptors, like plateia Branchiane or the golden plateia or plateia in Koressos. However, it does little to clarify what the plateia in IvE 3080 is, since here the plateia has neither a precise topographical descriptor, nor is it modified by an adjective. Are we really to think that IvE 3080 records that all of the people who lived and/or worked along the entire processional route, honoured Damianus? This would include everyone along the street between the Magnesian Gate (fig. 1, 10) and the State Agora (fig. 1, 18), the entire Kuretenstraße and Marmorstraße, as well as the street from the theatre to the stadium/Vedius Gymnasium (plateia Branchiane or plateia in Koressos [?]; fig. 1, 78), and beyond. This does not easily parallel with IvE 672, where a very topographically discrete collective, the people of the Tetragonos Agora, honour him. More importantly, not only is the agora a physical 'district', but also the "people of the agora " shared a common identity, linked together by their work as makers and sellers, as people involved in commerce in the agora. What would be the basis of the 'collective' identity of the plateia, if it meant the whole processional way? Such an inscription might make sense if Damianus was honoured for a major contribution to the goddess Artemis and her temple. Indeed, in IvE 3080 he is honoured as panegyriarch of the great Ephesia, but this is only one of several benefactions listed in the inscription, and it is not highlighted in the same way as are, for example, his contributions of grain and money.

\footnotetext{
${ }^{28}$ IvE VII 1 (1981) p. 74.

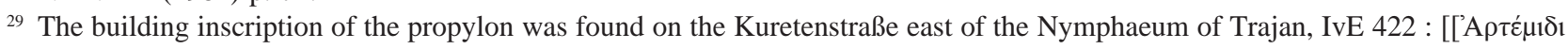

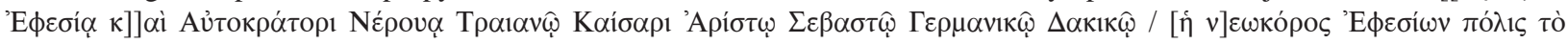

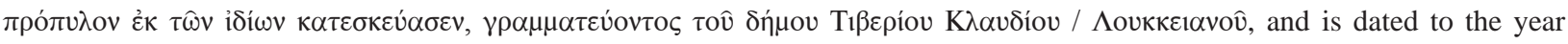
114/15 by the titulature of Trajan as aristos (optimus). On the propylon, see F. Miltner, XXII. Vorläufiger Bericht über die Ausgrabungen in Ephesos, ÖJh, 44, 1959, Beibl. 346; W. Alzinger in: RE Suppl. XII (1970) 1598 s. v. Ephesos, plan 2, nr. 28.

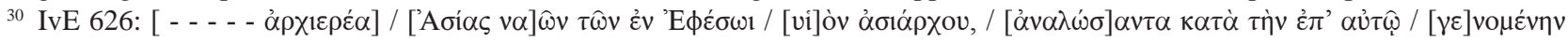

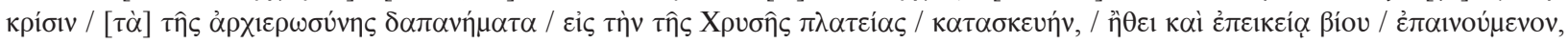

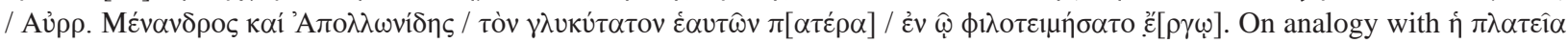

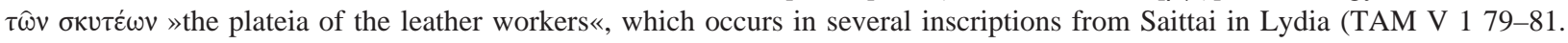
146), perhaps the X $\rho v \sigma \hat{\eta} \pi \lambda \alpha \tau \varepsilon \hat{\imath} \alpha$ is the street in Ephesos where workers in gold were established.

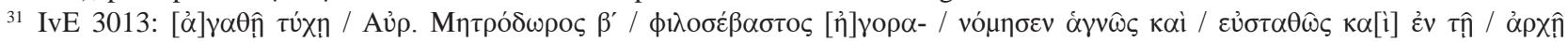

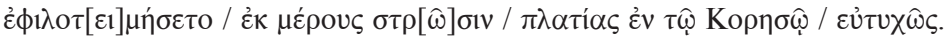

32 H. Thür, Das Hadrianstor in Ephesos, FiE XI 1 (1989) 72. See also Scherrer (note 26) 81, and Knibbe - Thür (note 7) 86.
} 
The solution that I propose is to interpret the plateia in IvE 3080 as a particular broad colonnaded street, which may well have been part of the processional route, but not as the entire processional route. Both IvE

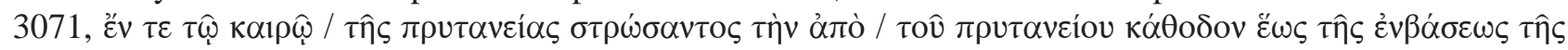
$\pi \lambda \alpha \tau \varepsilon i \alpha \varsigma$, »in the time of his prytany, he paved the descending road from the prytaneion to the entrance of

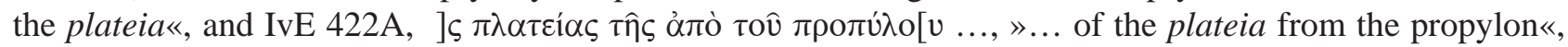
the fragmentary architrave inscription found near Hadrian's Gate identify possible streets: the Kuretenstraße and the Marmorstraße, respectively ${ }^{33}$. The argument for the Marmorstraße is stronger since we know that in the Roman and late Roman periods the Kuretenstraße was called the Embolos, and that the people of the area called themselves the Emboleitai. As for the Marmorstraße, we do not know its ancient name, but it may well have been the plateia $^{34}$. IvE 422A is an especially tantalizing bit of evidence to reinforce this view because the propylon has been identified as Hadrian's Gate, and one can easily read the fragmentary text ] $\varsigma \pi \lambda \alpha \tau \varepsilon i \alpha \varsigma$ $\tau \hat{\eta} \varsigma \dot{\alpha} \pi \hat{o} \tau o \hat{v} \pi \rho \circ \pi \dot{\lambda} \mathrm{o}_{0}[\mathrm{v} . .$. , as describing a colonnaded road (a plateia) starting from the propylon and leading towards the theatre and even beyond it.

If the plateia of IvE 3080 is the Marmorstraße, we need to determine its character in order to get a sense of who the people of the plateia were. As it leads from Hadrian's Gate (fig. 1, 52) the road passes the plaza in front of the Library of Celsus and becomes the Marmorstraße proper. It is bordered on the west side by a colonnade, the 'Neronische Halle', elevated about $3 \mathrm{~m}$ above the street levels which belongs to the Tetragonos Agora proper. Behind the colonnade on the east side of the road is a row of tabernae, some of which are part of the same insula as the so-called Freudenhaus (fig. 4$)^{35}$. The colonnades on both sides of the road, and presumably the tabernae, at least on the east side, continue on for about $150 \mathrm{~m}$ to the theatre. Beyond the theatre, the colonnaded road continues about another $600 \mathrm{~m}$, and is bordered by tabernae all the way to the stadium and the Vedius Gymnasium. Whether this whole colonnaded road from the Gate of Hadrian to the Vedius Gymnasium, or only a portion of it is the plateia named in IvE 3080 is difficult to determine given the current state of knowledge of road names in Ephesos. However, it seems fairly clear what the character of the whole Marmorstraße/plateia is as we have traced it from Hadrian's Gate and beyond: it was lined with tabernae ${ }^{36}$. I suggest that the toponym »plateia « in IvE 3080, then, refers to those people whose shops and work shops lined this road. So, like the "people of the agora " who belonged to the various associations of workers whose commercial enterprises were located in the agora, »the people of the plateia « were also linked by their commercial interests which were located on the road called the plateia.

The kind of collectives represented by IvE 672 and IvE 3080 encompass more than the needs of individual workers' or professional associations, whose main concerns were the regulation of the practice of a specific trade and its economics, burial and sociability ${ }^{37}$. IvE 672 and 3080 represent collectives made up of different commercial and manufacturing enterprises whose union was determined by topography, rather than by any other intrinsic interest. They may be compared to associations of merchants whose shops are located in a modern North American mall, or to merchants' associations on high streets in London. In an ancient city like Ephesos, the purpose of such associations might be very practical and quotidian, and concerned with the maintenance and appearance of the common space they shared, the agora or the plateia. This may have involved - and this is speculation - seeing to the day to day tidiness of their street through trash removal, maintenance of proper drainage, and regulation of shop frontage. Indeed, one can well imagine that merchants on the same street needed to work together to keep their area easy to work in and appealing to customers.

Furthermore, I suggest that the collectives represented in the toponyms of IvE 672 and 3080 are based on commercial interests located in particular places, rather than on residence. This is especially clear if we com-

\footnotetext{
33 »Als breite, marmorgepflasterte und hallengesäumte Straße - Plateia in römischer Zeit - kommen in der Nähe des Torbaues sowohl die >Marmorstraßeく als auch die >Kuretenstraßeく in Betracht.« Thür (note 32) 71-72.

${ }^{34}$ Unless it is the plateia in Koressos, see Scherrer (note 26) 63.

35 D. Boulasikis, Das sogenannte Freudenhaus zu Ephesos, ÖJh 72, 2003, 29-40. The tabernae on the west side of the house appear in all phases, see figs. 4-7.

${ }^{36}$ Although what we see today of the road is a manifestation of the $3^{\text {rd }}$ c. and later, it is highly likely that in the $2^{\text {nd }}$ c. the road was also lined with tabernae, see D. Knibbe, Der Asiarch M. Fulvius Publicianus Nikephorus, die ephesischen Handwerkszünfte und die Stoa des Servilius, ÖJh 56, 1985, 71-78.

37 van Nijf (note 11) 12-16 on evidence for associations regulating economic activities; 31-69 on associations' involvement in members' burials; 107-111 on sociability.
} 
pare them to another series of inscriptions from Ephesos, where groups identified by toponyms also undertake collective action, but specify that they are inhabitants of particular neighbourhoods. IvE 2298A, a fragmentary tomb inscription, records the commitment of people living around a certain plateia to care for the tomb of

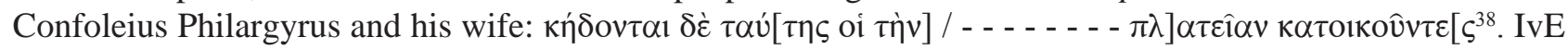
666a is an honorific monument for Fabius Faustinianus, a man who had held many civic offices in Ephesos.

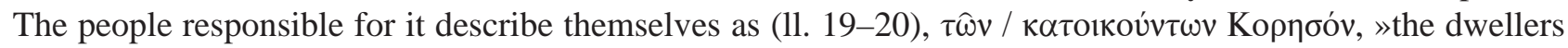

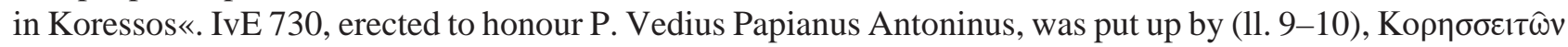

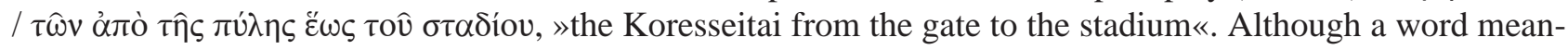
ing dwellers or inhabitants does not appear in this inscription, on analogy with IvE 666A, I think this is what Koresseitai means, especially since it is a collective noun derived from the name of a neighbourhood ${ }^{39}$. The dwellers around the Embolos are also named in some inscriptions ${ }^{40}$. IvE 1300 is a late antique epigram hon-

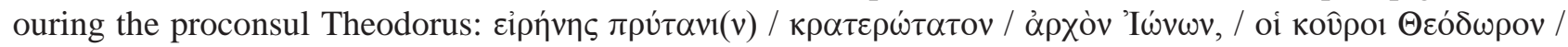

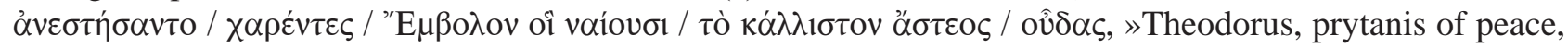
strongest leader of the Ionians, rejoicing, the young men who are dwellers in the Embolos, the most beautiful land of the city, set him up«. On analogy with the Koresseitai above, we also meet the Emboleitai in IvE 3059, an honorific monument erected to a priestess of Artemis who had renewed all the mysteries of the

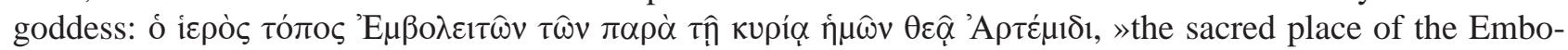
leitai, who are beside our lady goddess Artemis«. In these last four examples, the groups named by toponym

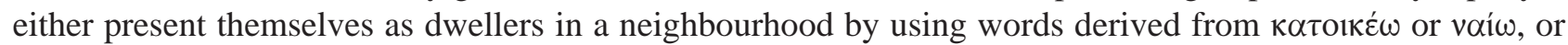

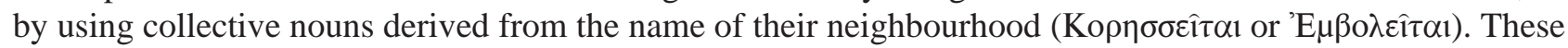
kinds of collectives based on residence are rather different and more broadly based than the collectives represented in IvE 672 and 3080, which I believe are commercial.

If we are correct, then, in identifying the "people of the agora « of IvE 672 with the merchants and workers in the Tetragonos Agora, and the "people of the plateia " of IvE 3080 with the merchants and workers along the Marmorstraße (and its extension beyond the theatre), can we come any closer to understanding why each collective chose to honour Damianus, as well as the process by which this kind of collective activity happened, and how these groups were related to the larger Ephesian body politic of the boule and the demos?

The benefits which Damianus conferred when he was grammateus and which are recorded on the parallel texts IvE 672 and IvE 3080 could easily be seen to profit the population of the entire city. Certainly, his provision of grain for 13 months for the troops returning from the Parthian war would have relieved the entire populace both of the burden of providing this support and also of the fear of famine due to the presence of an army. However, perhaps we can read this also as specifically benefitting the merchants that had their places in the agora and along the plateia. By hosting the Roman army, Damianus provided the commercial enterprises of the city with the possibility of reaping great profits from sales of goods and services to thousands of new potential customers in the city.

His hosting of the great Ephesia, a penteteric Artemis festival celebrated on a regional scale had the same potential for generating income for merchants ${ }^{41}$. People from elsewhere who came to Ephesos for the festival would necessarily spend money on food, lodging, sacrificial offerings and votives and, if so inclined, on souvenirs. The famous riot of the silver smiths at Ephesos was caused by the fear that Paul might succeed in convincing people to avoid the festivals of the godddess and so deprive the smiths of their lucrative livelihood

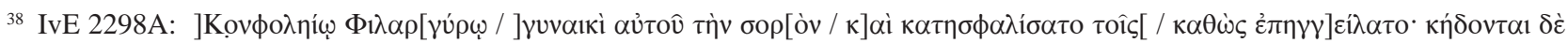

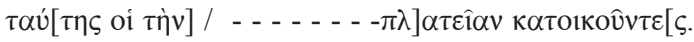

39 The location of the Koressos neighbourhood remains a thorny issue in Ephesian topography, on which see most recently Scherrer (note 26) 73 and D. Knibbe, Topographica Ephesiaca, ÖJh 71, 2002, 214-218.

40 There is a difference of opinion among the scholarship about whether the Embolos refers to a street or to a neighbourhood, with C. Foss, Ephesus after Antiquity (1979) 65 note 39 choosing the former, while J. Keil, Zum Martyrium des heiligen Timotheus in Ephesos, ÖJh 29, 1934, 88 argues for the latter. I think that the Embolos can mean both street and neighbourhood, depending on the inscription. The earliest inscription naming the Embolos dates to the time of Domitian and records the paving of the street called the Embolos (IvE 3008). The inscriptions which refer to Emboleitai, however date to a later period: IvE 1300, to at least the $3^{\text {rd }}$ c. (so Keil loc. cit.), and IvE 3059 to at least the time of Marcus Aurelius. I think that the street name comes first and is later also applied to the surrounding neighbourhood, so that we get »dwellers around the Embolos«.

${ }^{41}$ See note 15. 
selling silver statuettes of Artemis ${ }^{42}$. Furthermore, if, as I suggested above, Damianus spent more than the 4,500 denarii limit on the neccessities for the festival, it is likely that these 'extras,' whatever they were, were provided locally.

Damianus' promise of an oîko or hall in the Baths of Varius may also also have been particularly welcome to members of associations. Although the IvE 672 and 3080 are very vague on its nature, in numerous inscriptions, the word oîkos does mean the 'clubhouse' of an association ${ }^{43}$. If this is the case here, then Damianus was providing a place of sociability for these associations. Even if the oîko $\varsigma$ in these inscriptions is not a clubhouse, but simply a room in the Baths of Varius, the people of the agora and the plateia were particularly well located to enjoy the amenities provided by the structure.

The depositing of money into the coffers of the city by Damianus during his term as grammateus may also be interpreted as of particular benefit to these collectives of merchants. One of the ways that cities earned money was through rent on buildings. If the stoai of the agora and the colonnades and tabernae of the plateia were owned fully or partly by the city it is likely that the merchants who occupied them paid rents to the city $^{44}$. Honest dealing by Damianus and his deposit of money to the civic treasury may well have made the merchants who were leasing space a little more confident that there would be no increase in their rents. In short, although the benefactions were of general benefit to all Ephesians, they can also be seen to profit specifically the people of the agora and the plateia, who were engaged in commerce in these areas. Indeed, this is perhaps why the plateia addresses Damianus as their »own benefactor and incomparable in all things «, tòv

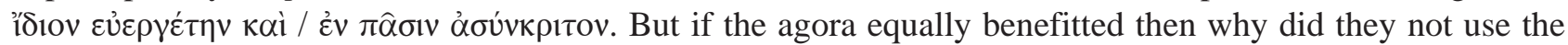

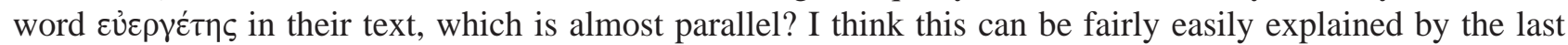
few lines of IvE 672. Where IvE 3080 uses the word euergetes, IvE 672 is less direct, indicating by the

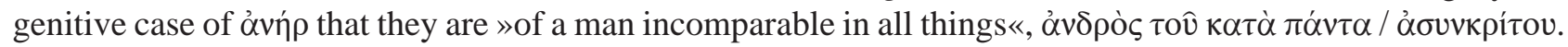
The language of possession reflects the sense in which a benefactor or patron 'belongs' to his client and the client 'belongs' to the benefactor.

\section{A single honorific decree}

The benefactions conferred by Damianus can be seen to have profitted the city as a whole and also the groups named in IvE 672 and IvE 3080. A study of the stones in Ephesos and of the squeezes in Vienna has lead me to conclude that the texts were commissioned at the same time and were likely carved in the same workshop. Indeed, the great similarity between the texts and, the fact that the inscriptions name no benefaction that can be seen to benefit only the plateia and the agora, suggests to me that they stem from a single honorific decree of the boule and the demos at Ephesos. In other words, these texts can be viewed as part of a more widespread phenomenon identified by $\mathrm{O}$. van Nijf wherein "associations were sometimes involved in the honorific practices of the city as a whole « ${ }^{45}$. In other words, associations, like the agora and the plateia, spurred on by honorific decrees of the boule and the demos, erected honorific monuments to civic benefactors, and so participated in the public discourse of the patron-client relationship. In doing so, they showed themselves to conform to the aspirations and commitments of the city. At the same time, they distinguished themselves as groups worthy of the benefactor's future attentions. And if I am correct in my identification of the agora and the plateia as workers and merchants bound together through sharing common commercial space, then they might hope that help with infrastructure in their specific areas might be forthcoming from a benefactor like Damianus ${ }^{46}$.

\footnotetext{
${ }^{42}$ Acts 19, 25-27.

${ }^{43}$ For e. g. see G. Mendel, Inscriptions de Bithynie, BCH, 1901, 36 no. 184; J. P. Waltzing, Etude historique sur les corporations professionelles chez les romaines (1895-1990) III no. 217. 218. More recently see I. Dittman-Schöne, Die Berufsvereine in den Städten des kaiserzeitlichen Kleinasien (2001) 42-49 and H. Schwarzer, Vereinslokale in Pergamon, in: U. Egelhaaf-Gaiser A. Schäfer (eds.), Religiöse Vereine in der römischen Antike (2002) 221-260.

44 A. H. M. Jones, The Greek City from Alexander to Justinian (1940) 246.

45 van Nijf (note 11) 125.

${ }^{46}$ The best example at Ephesos of a benefactor assisting an entire commercial area is M. Fulvius Publicianus Nikephorus' provision of work space in a colonnade for numerous workers' associations on which see Knibbe (note 36).
} 
We can reconstruct the evidence for this by briefly considering the the physical forms of IvE 672 and IvE 3080 (fig. 2. 3). First, I think that neither monument is complete. In antiquity both monuments would have had a separate upper moulding or plinth upon which the base of the statue stood ${ }^{47}$. The reuse of so many honorific bases in later walls and constructions in Ephesos resulted in the separation of shafts of the bases from their upper mouldings or plinths, and the separation of plinths from statues. The first editors of each of the stones, R. Heberdey and J. Keil respectively, were quite aware of this since each stone is described as a »Basis Mittelstück«. It is also likely that each text is incomplete, missing a formulaic prescript which would have been inscribed on the plinth. Although J. Keil thought that IvE 3080 could be grammatically complete

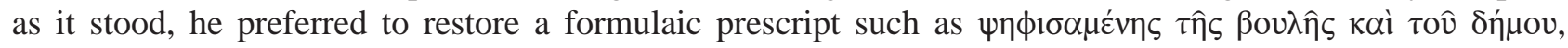
»the boule and the demos decreed «, indicating a successful vote of the boule and the demos ${ }^{48}$. He proposed

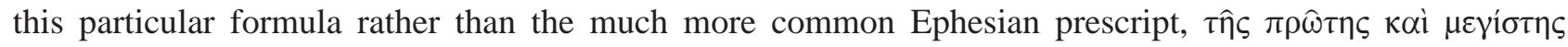

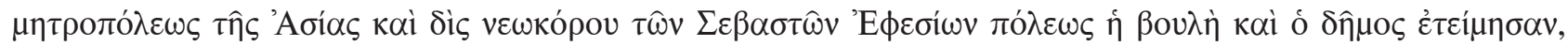
»the boule and the demos the first and greatest twice neokorate deme of the Ephesians honour «, because of the grammatical difficulty posed by having two nominative subjects. However, a prescript using either formula may be correct ${ }^{49}$.

R. Heberdey did not restore a formulaic prescript for IvE $672^{50}$, although in its current state the text is grammatically incomplete, lacking a subject in the nominative case. Therefore, restoration of the formulaic

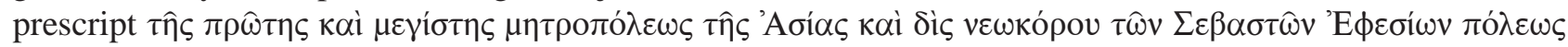

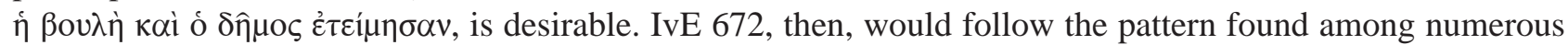
honorific texts at Ephesos where the formulaic prescript indicating the action of the boule and the demos is paired with a genitive absolute at the conclusion of the inscription, which indicates who set up and paid for

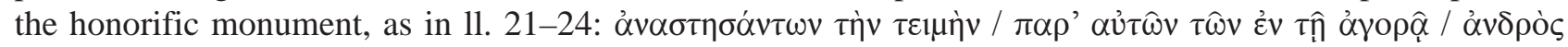
$\tau 0 \hat{v} \kappa \alpha \tau \dot{\alpha} \pi \alpha \dot{v} \tau \alpha$ / $\dot{\alpha} \sigma u v \kappa \rho i ́ \tau o v^{51}$.

The editors of »Inschriften von Ephesos « have related two other very fragmentary inscriptions to the parallel texts. IvE 672A is clearly an honorific inscription erected for a Damianus. Like so many honorific inscriptions, it begins with a fragmentary, but plausibly restored, formulaic prescript which is followed by the almost complete name of Damianus, in the accusative case ${ }^{52}$. The text breaks off in the next line with the word $\phi 1 \lambda 0 \tau \varepsilon \mu \iota \hat{\omega} v$. It is impossible to determine whether this was followed by anything like the parallel texts, or refers to other benefactions of Damianus. IvE 672B has been related to the parallel texts because it contains fragments of words that appear in them: $\delta \varepsilon] \kappa \alpha \tau \rho \varepsilon i[\varsigma$ and $\mu v] \rho ı \alpha \delta \alpha \varsigma \varepsilon^{\prime}\left[\kappa^{\prime}\left[\sigma_{1}^{53}\right.\right.$ has been related to Damianus' provision of grain for the army of Lucius Verus. This text may have a greater likelihood of being related to the parallel texts, however it is impossible to know certainly given its fragmentary state. Studying the squeezes of IvE 672, 3080 and 672A and 672B made it very clear to me that there is a relationship in the letter forms between IvE 672 and 3080, whereas IvE 672A and B were neither related to each other, nor to IvE 672

\footnotetext{
${ }^{47}$ IvE 672 has a small square dowel hole on the upper surface of the base, while IvE 3080 has no evidence of holes on the top surface (personal observation, September 2005). However, the absence of dowel holes should not be taken to mean that there was no upper moulding or plinth, since numerous bases in Ephesos which certainly did have plinths for statues on top of their main shafts lack these.

48 J. Keil in: FiE III (1923) 161.

49 There is an example of the use of two nominative subjects in IvE 625: the first is the boule and the demos, with the verb understood, just as it is understood in IvE 3080. The second nominative names the person who promised the honour, the prytanis M. Aurelius Statilius Stratoneikos.

${ }^{50}$ Heberdey (note 10) 164-165.

${ }^{51}$ For further examples of this pattern, see IvE 627. 634. 637. 642.

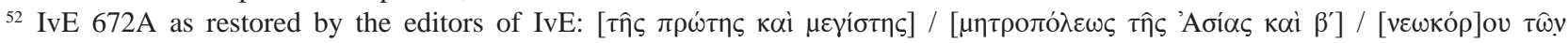

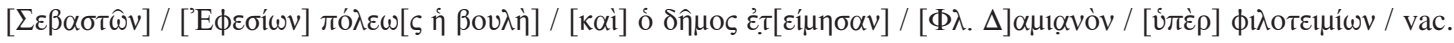

53 IvE 672B as restored in IvE: ]. [ $\quad \gamma \rho \alpha \mu \mu \alpha-$

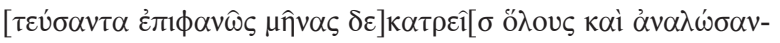

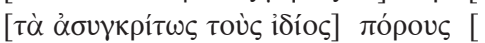

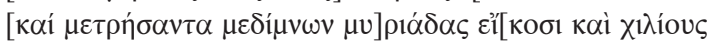

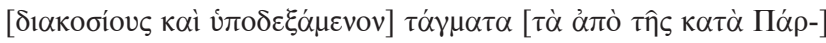

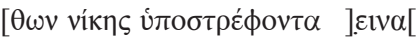


and $3080^{54}$. However, this only means that $672 \mathrm{~A}$ and B were not carved in the same officina as IvE 672 and 3080. Regardless of whether we have two or four inscriptions belonging to the series, the important point is to see collectives acting in tandem with the boule and the demos, and participating in the civic discourse of honours.

Two series of inscriptions from Side provide comparative examples of collectives described by toponyms honouring civic benefactors, and also shed further light on the process by which the honours were generated. Bryonianus Lollianus, his wife, Quirinia Patra, and their son, Bryonianus Iasonianus Seleukos were honoured

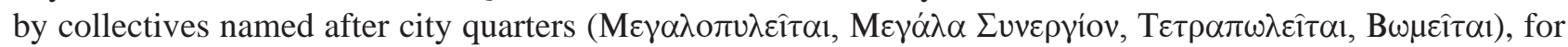
financing the repair an aqueduct which had been cut during the Gothic attack of $269^{55}$. This restoration of the water supply was a benefit which was enjoyed by the whole city, just as, or perhaps even more so, than Damianus' numerous benefactions to Ephesos listed in IvE 672 and IvE 3080. The toponyms of the Side inscriptions, however, appear to relate more closely to the inscriptions from Ephesos that name the Embolei-

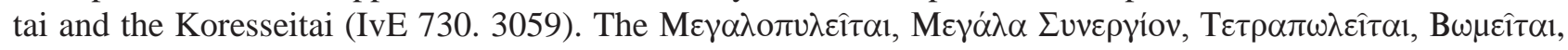
Emboleitai and Koresseitai all seem to refer to associations based on neighbourhood, or residence, that is people dwelling in a place, rather than what I have argued in the case of IvE 672 and 3080, associations of workers and merchants who happen to share the same physical space (agora and plateia). Does this influence the way that they were organized to undertake collective action?

The Side inscriptions are more informative than the Ephesos ones on this issue, and are slightly more complex in form, being half prose and half poetry. Let us take Side no. 105 as an example:

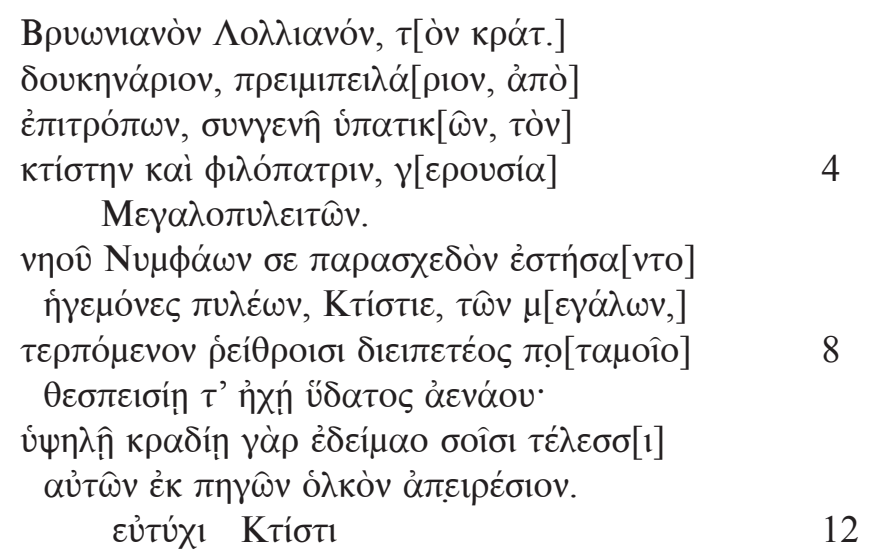

»Bryonianus Lollianus, egregius ducenarius, primus pilus, former procurator, descended from consuls, founder and lover of the fatherland, the gerousia of the Megalopuleitai honours. Beside the temple of the nymphs, the leaders of the Great Gate set you up, Ktistios, you who rejoice in the streams of the Zeus-sprung river and in the divine murmur of the ever-flowing water. For with your own money and lofty heart you built a boundless channel from those springs. Good luck, Ktistios!«

The first five lines of the text, composed in prose, name the honorand and his titles in the accusative case, and inform that the gerousia of the Megalopuleitai quarter was responsible for the erection of the inscription. A poetic text, which conveys similar information, follows. The other inscriptions of the group follow the same pattern, naming first the benefactor in the accusative and the gerousia of each quarter in the nominative as responsible ${ }^{56}$. Two inscriptions, also from Side, which honour a couple for putting on gladiatorial games and venationes are even more informative about the process. The archierea, Modesta, and her husband, Modestus

\footnotetext{
${ }^{54}$ I undertook a careful examination of the squeezes of IvE 672, 3080 and 672A and 672B at the Austrian Archaeological Institute in November, 2005.

55 J. Nollé, Side im Altertum II, Inschriften griechischer Städte aus Kleinasien 44 (2001) 398-415 nos. 105-110. On the location of the city quarters, see $402-403$.

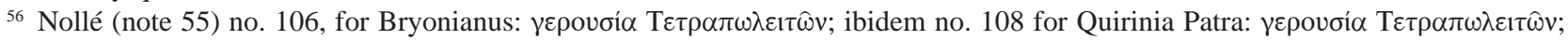

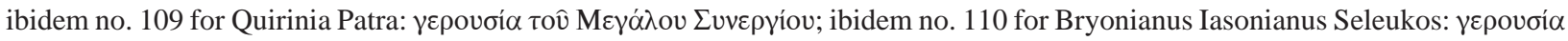

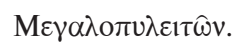




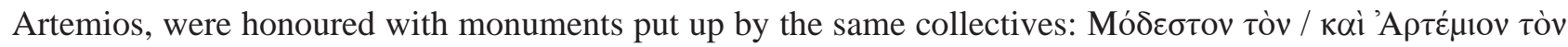

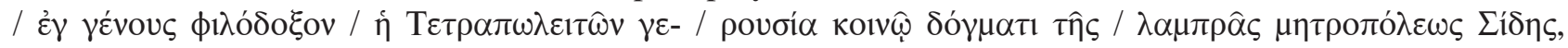
»Modestus, also known as Artemios, a lover of glory from his ancestors, the gerousia of the Tetrapuleitai set up, by common decree of the distinguished metropolis of Side. ${ }^{57}$ These texts not only indicate the role of the gerousiae of the neighbourhoods, but also the primary role of the metropolis, which presumably means the civic decision-making organs, the boule and the demos, in initiating the action.

These inscriptions from Side are important in emphasizing the role of the boule and the demos in initiating honorific decrees, and in presenting a model for the organization of collective action, via the gerousiae of neighbourhoods. However, we should not imagine that the same pattern holds for Ephesos. There is no evidence in the epigraphic record that shows what I have called neighbourhood collectives, like the Emboleitai and Koresseitai organized under the leadership of a gerousia or other named leadership. The only hint provided by the inscriptions is in IvE 1300, a late antique and poetic inscription, which says that the kovpor, "young men«, who dwell in the Embolos area honour Theodorus. Does kov̂por here mean an organization of young men (ephebes?) based around a gymnasium (which one?) in the neighbourhood, and so suggest that they were the basis of the neighbourhood's organization? This is entirely speculation and must be treated with caution especially because the inscription is late and poetic.

I think that it is possible to speculate with a little more certainty on how such collectives as the agora and the plateia at Ephesos came together to erect honorific monuments to T. Flavius Damianus. If I am correct in thinking that in each case the collective was made up of workers and merchants who were linked by the location of their business, then the organization of each group could be very informal indeed and would have been so of necessity. The Roman authorities could and did accept the existence of workers' or professional associations, and given the evidence of Side, also accepted associations based on neighbourhoods. The general model here is presumably Rome, where the vici were formal neighbourhood organizations with an organized leadership. The Romans evidently allowed other types of neighbourhood organization to remain according to local custom, as at Side ${ }^{58}$. However, they were reluctant to tolerate the creation of other types of associations for fear that they might become political ${ }^{59}$. In the cases of the plateia and the agora of IvE 3080 and 672, the creation of each collective was of necessity casual and, possibly even time-limited, restricted to erecting these two honorific monuments for Damianus. The formation of these temporary collectives had legitimacy because it was prompted, as I have argued above, by a decree of the boule and the demos: the agora and the plateia in undertaking collective activity were acting within the confines of a civic decree. Furthermore, the actual meeting or coming together of each collective as a group to discuss the honours would have been an affair entirely non-threatening to the Roman authorities, if it employed the existing social networks of workers' or professional associations. This would have been a most simple and effective route to undertaking collective action. This also helps to explain how we get the parallel texts. It is possible that a 'meeting', however we may envision this, of (representatives of?) the two collectives, which were very close topographically, came up with a basic text which was passed on to the epigraphic officina, who in turn made certain decisions about the arrangement of the texts on the stones.

\section{Conclusions}

The parallel texts, IvE 672 and 3080, which record honours granted by »the people of the agora» and »the plateia « to T. Flavius Damianus for his outstanding benefactions widen our perspective on honorific practices in Ephesos. I have argued that the parallel inscriptions were prompted by a decree of the boule and the

57 Nollé (note 55) no. 111, and see no. 112 for Modesta’s monument which was also erected by the same collective.

${ }^{58}$ But note Alexandreia Troas, which becomes a Roman colonia between 40 and 31 BC. It adopts a Roman style constitution with decuriones, populus, aediles, augures, etc. and was divided into at least 10 vici, several of which are recorded in inscriptions honouring imperial benefactors, see M. Ricl, Inscriptions of Alexandreia Troas, Inschriften griechischer Städte aus Kleinasien 53 (1997) 11-12 and nos. 16. 36 and 39.

59 Plin. epist. 33 and 34 where Pliny requests permission from Trajan for the formation of a collegium fabrorum at Nicomedia in order to fight fires like a recent one that had destroyed several private and two public buildings. To persuade Trajan, Pliny writes that he will ensure that only real fabri will be admitted to the collegium: Ego attendam, ne quis nisi faber recipiatur ... 
demos of the city: if our monuments were complete, this would have been indicated by a formulaic prescript inscribed on the plinth, which is absent from both IvE 672 and 3080, having been detached when the stones were reused in later structures. Thus, the agora and the plateia, as general and perhaps even specific beneficiaries of Damianus' generosity were taking part in the dialogue of benefactor and city which found its expression in honorific monuments. In doing so, they professed solidarity with civic goals but also distinguished themselves as collectives worthy of the benefactor's attention in the future. I have also attempted to clarify who the people of the agora and the people of the plateia were. They ought to be regarded as collectives of commercial enterprises located respectively in the Tetragonos Agora, and, along the Marmorstraße and its extension to the Vedius Gymnasium. Each collective was evidently broader than a single workers' or professional association: what bound each together was the fact that they were all doing business in a shared urban space, and as neighbours in this respect, they had certain common goals that might be served through collective action.

\section{Acknowledgements}

Warm thanks to colleagues in Austria who took the time to share with me their ideas and expertise on things Ephesian: Maria Aurenhammer, Johanna Auinger, Anton Bammer, Ulrike Muss, Patrick Sänger, Peter Scherrer, Alexander Sokolicek, Martin Steskal, Gilbert Wiplinger, Heinrich Zabehlicky, and especially, Hans Taeuber. My deep gratitude to Prof. Dr. Friedrich Krinzinger, director of the Austrian Archaeological Institute for kind permission to access squeezes and sketchbooks in Vienna, and to the Direction and staff of the Efes Müzesi, Selçuk for permission and assistance with inscriptions in storage.

This research was made possible by a generous grant from the Social Sciences and Humanities Research Council of Canada.

\section{Dr. Angela Kalinowski}

Department of History, University of Saskatchewan, Saskatoon, Saskatchewan, Canada S7N 5A5

E-Mail:angela.kalinowski@usask.ca

References of figures: Fig. 1. 4: ÖAI (St. Klotz, Ch. Kurtze); fig. 2. 3: ÖAI; all figures by courtesy ÖAI. 